\title{
MANAGEMENT CONTROL
}

Theories, Issues and Practices 


\section{MANAGEMENT CONTROL}

\section{Theories, Issues and Practices}

Edited by

Anthony J. Berry, Jane Broadbent and David Otley 
Selection, editorial matter and Chapters 1-6

(C) Anthony J. Berry, Jane Broadbent and

David Otley 1995; other chapters (C) individual authors 1995

All rights reserved. No reproduction, copy or transmission of this publication may be made without written permission.

No paragraph of this publication may be reproduced, copied or transmitted save with written permission or in accordance with the provisions of the Copyright, Designs and Patents Act 1988, or under the terms of any licence permitting limited copying issued by the Copyright Licensing Agency, 90 Tottenham Court Road, London W1P 9HE.

Any person who does any unauthorised act in relation to this publication may be liable to criminal prosecution and civil claims for damages.

First published 1995 by

MACMILLAN PRESS LTD

Houndmills, Basingstoke, Hampshire RD21 2XS

and London

Companies and representatives

throughout the world

A catalogue record for this book is available from the British Library.

$\begin{array}{rrrrrrrrrr}10 & 9 & 8 & 7 & 6 & 5 & 4 & 3 & 2 & 1 \\ 04 & 03 & 32 & 31 & 00 & 99 & 98 & 97 & 96 & 95\end{array}$


To those who have supported us throughout the project and continue to give us their support 


\section{Contents}

Preface ix

Notes on the contributors $\quad$ xii

Acknowledgements $\quad$ xvi

PART I THEORIES OF CONTROL

1 The domain of organisational control 3 Anthony J. Berry, Jane Broadbent and David Otley

2 Approaches to control in the organisational literature 17 Anthony J. Berry, Jane Broadbent and David Otley

3 Structures of control

Anthony J. Berry, Jane Broadbent and David Otley

4 Procedures for control

Anthony J. Berry, Jane Broadbent and David Otley

5 The context of control

Anthony J. Berry, Jane Broadbent and David Otley 
9. Control of embedded operations: spanning traditional boundaries 139 Anthony J. Berry

10 Economics and control

Willie Seal

11 Performance indicators and control in the public sector 163 Peter Smith

12 Organisational culture and control Kim Langfield-Smith

\section{PART III PRACTICES OF CONTROL}

13 Management control systems of Japanese companies operating in the United Kingdom

Istemi S. Demirag

14 Management accounting: the Western problematic against the Japanese application Karel Williams, Colin Haslam, John Williams, Makoto Abe, Toshio Aida and Itsutomo Mitsui

15 Management control in an airline 238

C. Wilkinson

16 Control and the National Health Service: some psychology of managing health care with cash budgets and cash limits Derek Purdy

17 Management control in schools Jane Broadbent

18 Management control in the financial services sector 283 Kim Soin

19 Manufacturing accountability

T. Colwyn Jones and David Dugdale

20 Endpiece

Anthony J. Berry, Jane Broadbent and David Otley

Bibliography 


\section{Preface}

Following the publication of two monographs, New Perspectives in Management Control (Lowe and Machin, 1983) and Critical Perspectives in Management Control, (Chua, Lowe and Puxty, 1989), members of the Management Control Association conceived the idea of collaborating to produce a textbook. The book was intended to provide a broader and more flexible text on management control that those which were available at the time. The book which we have produced reflects this original aim, along with the interests and idiosyncracies of the various contributors. As such it should not be seen as providing the last or the definitive word on management control, but instead as a starting-point. The book does accept that managers are central in the process of managing, but it does not accept the concept of 'managerialism' uncritically. It seeks to provide ideas which will stimulate a wider search for knowledge, rather than close down possibilities.

The book is aimed at those attending both MBA and specialist masters courses as well as advanced undergraduate courses. It should also provide food for thought for practising managers. We do not aim to provide a prescriptive and structured course outline, but to provide a resource which can be 'dipped into' on a flexible basis. The volume falls into three parts, each with a rather different focus and each of the chapters is self-standing and can be amalgamated into courses to suit individual preferences.

In Part I, the aim is to extend the boundaries of management control and it therefore explores the various approaches to control which have been adopted by those writing on the subject. In Chapter 1 we examine the domain of organisational control, focusing on systems approaches. Chapter 2 reviews some of the approaches to control which have their roots in organisational literature. In Chapter 3 the way in which organisations and tasks are structured in order to achieve control is discussed, while Chapter 4 looks at the more detailed procedures which can be used. Finally in this Part, chapter 5 explores the context in which control exists. It discusses the extent to which organisations are constrained by external forces yet are able to reject or buffer the effect of unwanted changes. 
It should be stressed that Part I does not seek to prescribe the 'one best way'. We do not believe that this is possible. Thus the material merely seeks to show the various dimensions of control which need to be considered by the practising manager as well as the different ways in which control can be conceived. Our hope is that a greater set of possible solutions can be generated as wider understandings are achieved.

In Part II we narrow the focus rather more and examine particular issues of control which may be encountered in various different types of organisation. Again we do not pretend that the list is exhaustive of the issues which could be raised, but we do feel a range of topical and relevant areas have been addressed. Chapter 6 examines the general use of one of the most pervasive tools of control, accounting. Chapter 7 reviews the issue of how to control in divisionalised companies and Chapter 8 examines issues of strategy. In Chapter 9 the issues of controlling companies which exist in close relationships with others, those which are embedded in production chains, is addressed. The contribution that economics can make to control is examined in Chapter 10. In Chapter 11 the use of performance indicators as a means of control in the public sector is the area for discussion. Chapter 12 reviews the literature which has seen culture as either a means to control or an element which impinges on the possibilities of achieving control. Following on from this are two chapters which consider the impact of another culture, the Japanese, on controls in particular situations. Chapter 13 looks at the way Japanese subsidiaries operating in Europe are controlled and Chapter 14 takes a broader look at the extent to which it is possible to speak of a 'Japanese approach' to control.

Part III is more specific again, this time focusing on control in particular organisational settings. The settings chosen represent a variety of contexts and the different authors have taken a variety of approaches. Some chapters are stand-alone case studies whilst others combine case material with more theoretical reflection. The five chapters cover the airline industry, the NHS, schools, financial services and manufacturing. Finally, Chapter 20 reflects on the book as a whole.

There are other issues which the book has not been able to cover. Issues of gender and power are ones which we have not addressed directly and no doubt many other aspects could be listed. The two monographs mentioned earlier cover important areas and readers are recommended to explore these books to fill in some of the omissions or to delve more deeply into other topics of interest. We have also sought to provide a comprehensive bibliography to enable deeper study of particular areas. Let us stress once more that this book is merely a starting point, offering some ideas about organisational control, but never pretending to have all the answers. The sheer complexity of human society and the creativity of individuals suggests we never will have all the answers to achieving total control. Our belief is that this is probably a good thing. 
In writing this book we have had the support of a great number of people. Direct contributors are listed separately and our debt to them is obvious, but there are others who have given background support and assistance without which we could not have completed this project. Mandy Lowndes has provided secretarial support cheerfully and efficiently and David Simon has patiently read and commented on early drafts of some chapters. Members of the Management Control Association have commented on other chapters which have been presented at some of our regular workshop meetings. Our thanks go to everyone concerned.

ANTHONY J. BERRY

JANE BROADBENT

DAVID OTLEY 


\section{Notes on the contributors}

Makoto Abe is Associate Professor in the Economics Department of the University of Oita in the South of Japan. By training and background, he is a specialist on labour and employment relations in Japanese manufacturing. His interest in comparative studies was stimulated by a year's sabbatical in Britain.

Toshio Aida is Professor in the Sociology Department at Hosei University in Tokyo. His activities and publications span a broad range in the social sciences. At present, he is particularly interested in Japanese overseas manufacturing and the changing balance between Japanese direct investment in Western market access and in Asian low wage production.

Anthony J. Berry is Senior Lecturer in Management Development in the Manchester Business School, which he joined after some years in the British and the American aircraft industries. His research interests are management development, consultancy and management control.

Jane Broadbent is a lecturer at the Sheffield University Management School, where she teachers Management Accounting and Management Control. Jane is a member of the Chartered Association of Certified Accountants, a qualification gained whilst working as an accountant in the National Health Service. Her research interests focus on the reforms in the public sector and the role of accounting in promoting change.

M. Broadbent holds the post of Head of Department of Accounting and Finance at Manchester Metropolitan University. He is a Fellow of the Chartered Association of Certified Accountants. He has written texts in managing financial resources and cost and management accounting. His research interests focus on the interface between accounting mechanisms and management control systems in large organisations. 
Alan Coad is a Principal Lecturer at Sheffield Hallam University. Formerly a management accountant in both private and public sector organisations, his main research interests lie in exploring the interrelationship of strategy and management accounting.

J. Cullen is Principal Lecturer in Management Accounting at Sheffield Hallam University. He joined the university in 1983 after working in several line management and senior management posts in industry. He is the co-author of a book called Managing Financial Resources and has written numerous case studies, articles and chapters with other colleagues. His current research interest include the impact of environmental uncertainty on management control systems, the links between management control systems and strategy, management control systems in multinationals, management control systems in small businesses and issues surrounding business failure situations.

Istemi S. Demirag is Lecturer and Grant Thornton Fellow in Accounting and Financial Management at the Sheffield University Management School. His current research interests include financial aspects of innovative management, strategy and performance evaluation and management in multinational companies. He lectures in financial accounting and management of international business.

David Dugdale holds the post of Associate Dean in the Bristol Business School, a faculty of the University of the West of England, Bristol. He spent sixteen years in industry before joining Bristol Polytechnic in 1987. CIMAqualified, Dr Dugdale has worked as a management accountant in industry and has developed several research interests in the field of management accounting. Working with Colwyn Jones he has published a number of papers in the professional and academic press. Together with Colwyn Jones he Ras a current research project on 'Throughput Accounting'.

T. Colwyn Jones is Principal Lecturer in the School of Sociology, and Research Fellow in the Centre for Social and Economic Research (CESER) at the University of the West of England, Bristol. Since 1975 he has been teaching sociology to accounting undergraduates. He is the author of an undergraduate text, Accounting and the Enterprise: A Social Analysis (1995) and a number of papers (many with David Dugdale) on accounting rationality, accounting and technology, investment appraisal, and change in costing systems. His current research focuses on the role of management accounting in changing manufacturing organisations, especially the development of 'Throughput Accounting'.

Colin Haslam is Reader in the Business School at East London University. Before studying under John Williams at Aberystwyth, he worked for British 
Nuclear Fuels and has published on nuclear waste. He leads the statistical work for team research with John and Karel Williams which benefits hugely from his unequalled grasp of official sources.

Kim Langfield-Smith is a Senior Lecturer in the Department of Accounting and Finance at Monash University, Clayton, Australia, with main teaching interests in management accounting and control systems. Prior appointments were at the Universities of Melbourne and Tasmania. Before entering academic life she worked as an accountant in several commercial organisations. Her research interests are in the area of management control systems. Current topics include studying the interface between business strategy and management control systems, and investigating new developments in performance measures. She has publications in journals in both the accounting and management fields.

Itsutomo Mitsui is Professor in the Economics Department at Komazawa University in Tokyo. He has mainly researched the problems of small and medium enterprises and the organisation of supplier networks. As well as writing for an academic audience, he has acted as consultant and adviser to Western organisations such as the European Community. This is the second project on which he has collaborated with Colin Haslam and Karel Williams.

David Otley is KPMG Peat Marwick Professor of Accounting at the Lancaster University Management School, and General Editor of the British Journal of Management. He has taught and researched management control for many years and is joint author (with Clive Emmanuel and Ken Merchant) of the text Accounting for Management Control (1990). His current interests are in the use of performance-related pay, and in the impact of corporate strategy on management control systems design and use.

Derek Purdy is Reader in Accounting at the University of Reading. His work has been published in a wide variety of journals which relate accounting and management issues. He has published extensively about accounting for convertible debt. His main research interest lies in the effects of financial management accounting data upon people, their organisations and control issues, generally construed from a psychological perspective.

Willie Seal graduated in economics from the University of Reading and worked for Touche Ross as an articled clerk. He has lectured at Bath, Nottingham Trent and Sheffield Hallam Universities. He is now Research Leader in Management Accounting and Corporate Finance in the School of Financial Studies and Law at Sheffield Hallam University. One of his main research interests has been the application of institutional economics to accounting and management control (which was the subject of his doctoral 
thesis). More recently he has led a research project on accounting in the Czech Republic and the relationship between management control and professionalisation in UK banking.

Peter Smith is Senior Lecturer in Economics, Finance and Accountancy at the University of York. He has worked in local government and at the University of Cambridge medical school. His research interests are public sector efficiency and public finance, topics on which he has published extensively.

Kim Soin is a researcher in management accounting at Sheffield Hallam University. Her primary research interest is activity based costing in the UK financial services sector.

C. Wilkinson is the Deputy Director (Academic Affairs) of Southampton University Management School. Prior to this appointment in 1993, he was a Lecturer in Accounting and Finance at Lancaster University for seven years. His role at Southampton University Management School is the organisation and management of the full-time and part-time MBA programmes and teaching courses in the areas of accounting and finance, control and strategic planning systems. His research interests are focused upon the design of control systems, particularly the development of organisational and managerial performance measures and reward systems.

Karel Williams is a Reader in the Department of Accounting and Finance at the University of Manchester. He studied nineteenth-century history and published Pauperism to Poverty (1981) before being radicalised by British deindustrialisation and taking up contemporary issues through team work with Colin Haslam and John Williams.

John Williams has recently retired from a chair at the University of Wales, Aberystwyth, after some thirty years as historian of industrial South Wales. He has published extensively on South Wales coal-mining and edited the standard collection of Welsh historical statistics. Since Why are the British Bad at Manufacturing? (1983) he has worked mainly on more current issues with Karel Williams and Colin Haslam. 


\section{Acknowledgements}

The editors and publishers wish to thank the following for permission to reproduce copyright material:

Harvard Business School Case Services, for Figure 7.1, from B.R. Scott, Four Stages of Corporate Development - Part I (1971); Basil Blackwell, for Figure 7.3, from M. Goold and A. Campbell, Strategies and Style: The Role of the Centre in Managing Diversified Corporations (1987); Harvard Business Review, for Figure 7.2, from R.S. Kaplan and D.P. Norton, 'The balanced scorecard - measures that drive performance' (1992), (c) the President and Fellows of Harvard College, all rights reserved; Pitman, for Figure 8.1. from R.D. Stacey, Strategic Management and Organisational Dynamics (1993); Accounting, Organizations, and Society, for Figure 12.1, from E.G. Flamholtz, T.K. Das and A.S. Tsui, 'Toward an integrative framework of organisational control' (1985), for Figure 12.2, from J.G. Birnberg and C. Snodgrass, 'Culture and control: a field study' (1988), and for Figure 12.3, from R. Simon, 'The role of management control systems in creating competitive advantage: new perspectives' (1990); Sage, for Box 12.1, from G. Morgan, Image of Organisation (1986). Simon \& Schuster, for Box 12.4, from R.T. Pascale and A.G. Athos, The Art of Japanese Management (1981); Melbourne Case Study Services, for Box 12.6, from A. Sinclair and J. Baird, SPC: New Deal (n.d.); Prentice-Hall, for Box 19.2, from A.G. Hopwood, Accounting and Human Behaviour (1974); Penguin Books Ltd for an extract from The Art Japanese Managment by Richard Tanner Pascale and Anthony G. Athos (Allen Lane, 1982); Elsevier Science Ltd for an article from Long Range Planning, vol. 20, no. 5, pp. 42-52: 'Managing diversity: strategy and control in diversified British companies's by M Goold and A. Campbell (1987) and extracts from Accounting Organizations and Society, vol. 10, no. 1; vol. 13, no. 5; and vol. 5, no. 2; An earlier version of Chapter 9 was published in the Leadership and Organisational Development Journal, 15 July, 1994, with permission. 
Every effort has been made to trace all copyright-holders but, if any have been inadvertently overlooked the publishers will be pleased to make the necessary arrangement at the first opportunity. 